\title{
Hematological, biochemical and ruminant parameters for diagnosis of left displacement of the abomasum in dairy cows from Southern Brazil
}

\author{
Felipe Cardoso de Cardoso(1), Vanessa Sinnott Esteves $^{(1)}$, Simone Tostes de Oliveira ${ }^{(1)}$, Camila Serina Lasta ${ }^{(1)}$, \\ Stella Faria Valle ${ }^{(2)}$, Rómulo Campos ${ }^{(3)}$ and Félix Hilario Diaz González ${ }^{(1)}$
}

(1)Universidade Federal do Rio Grande do Sul, Faculdade de Veterinária, Laboratório de Análises Clínicas Veterinárias, Avenida Bento Gonçalves, o 9.090, Bairro Agronomia, CEP 91540-000 Porto Alegre, RS, Brazil. E-mail: cardosovet@terra.com.br, vanessastvs@yahoo.com.br, tostesimone@yahoo.com.br, camila.lasta@ufrgs.br, felix.gonzalez@ufrgs.br(2)Universidade de Passo Fundo, Faculdade de Agronomia e Medicina Veterinária, Campus Universitário, Bairro São José, CEP 99001-970 Passo Fundo, RS, Brazil. E-mail: stellavalle@upf.br (3)Universidad Nacional de Colombia, Departamento de Ciencia Animal, Campus Palmira, AA 237, Palmira, Colombia. E-mail: romulo.campos@ufrgs.br

\begin{abstract}
The objective of this work was to evaluate hematological, biochemical and ruminant parameters for diagnosis and treatment of the left displaced abomasum (LDA) in dairy cows, in the Plateau Region of Rio Grande do Sul, Brazil. Ruminant fluid, blood and urine samples were collected from 20 cows suffering LDA and from 20 healthy cows (control). The cows with LDA showed lower values of daily milk production, body weight and corporal condition score. The use of $\mathrm{pH}$ reagent strips showed to be functional in the field, when compared to a digital $\mathrm{pH}$ meter. Ruminant dynamics was damaged in cows affected by LDA, as it was evidenced by the higher reduction time of methylene blue. Serum values of lactate, beta-hydroxybutyrate, urea, albumin, free fatty acids and cholesterol shows to be auxiliary tools in the LDA characterization.
\end{abstract}

Index terms: abomasopexy, dairy production, ketosis, nonesterified fatty acids.

\section{Indicadores hematológicos, bioquímicos e ruminais no diagnóstico do deslocamento de abomaso à esquerda em vacas leiteiras do Sul do Brasil}

\begin{abstract}
Resumo - O objetivo deste trabalho foi avaliar indicadores hematológicos, bioquímicos e ruminais no diagnóstico e tratamento do deslocamento de abomaso à esquerda (DAE) em vacas leiteiras, na Região do Planalto do Rio Grande do Sul, Brasil. Foram coletadas amostras de líquido ruminal, sangue e urina de 40 animais, dos quais 20 vacas com DAE e 20 vacas clinicamente sadias utilizadas como grupo controle. Os animais com DAE, quando comparados ao grupo controle, apresentaram diminuição da produção de leite diária, do peso corporal e do escore condição corporal. A utilização de fitas reagentes para medição do $\mathrm{pH}$ ruminal demonstrou-se eficaz em campo, em comparação ao potenciômetro digital. A dinâmica ruminal apresentou-se prejudicada nos animais com DAE, o que foi evidenciado pelos valores aumentados do tempo de redução de azul de metileno. Os valores séricos de lactato, beta-hidroxibutirato, uréia, albumina, ácidos graxos livres e colesterol apresentam-se como ferramentas auxiliares na caracterização da doença.
\end{abstract}

Termos para indexação: abomasopexia, produção de leite, ácidos graxos não-esterificados, cetose.

\section{Introduction}

Clinical observations show that, in the State of Rio Grande do Sul, the displacement of the abomasum (DA) is an affection in high producing dairy herds. The prevalence of this disease varies in different dairy herds depending on geographical localization, handling practices, climate, and other factors. Among the abomasal volvulus diseases, the left displaced abomasum (LDA) prevails from 85 to $96 \%$ of the occurrences (Trent et al., 1990).
The DA is a multifactor syndrome in which the abomasal atony is the first symptom of its occurrence. Gas produced by abnormal microbial fermentation distends the abomasum and causes the displacement. Feeding with high levels of concentrate results in reduction of ruminant motility, and increases the accumulation of abomasal gas (Sarashina et al., 1991).

There is a direct relation between the negative energetic balance in pre-calving and the occurrence of LDA. This relation is one of the factors involved in the etiology of this disease (Cameron et al., 1998). Cows 
fed high energetic diets ( $>1.65 \mathrm{Mcal}$ of net energy of lactation per kilogram on dry matter basis), during the dry period, reach the calving with excessive weight. This may result in a decrease of dry matter intake, which exacerbates the negative balance of energy. During summer months, ingestion of dry matter is also detrimental because of the caloric stress, which predisposes cows to DA. High producing herds $(>7,000 \mathrm{~kg}$ per lactation) are associated to a higher index of DA (Radostits et al., 2000).

The diagnosis of ketosis before DA is also strongly associated to the occurrence of the disease (Geishauser et al., 1997). Ketosis can reduce the consumption of dry matter and the ruminant fulfillment, thus diminishing the motility of the other stomachs and, potentially, the motility of the abomasum. A small ruminal volume offers less resistance to the displacement of the abomasum (Van Winden \& Kuiper, 2003).

In Canada, the incidence of DA in animals in lactation is $2 \%$ (Geishauser et al., 1998). Approximately $24 \%$ of the specialized dairy cows herds have at least one case of LDA in a period of three years (Coppock et al., 1972).

Detilleux et al. (1997) reported that economic losses related to this disease are due to the reduction in milk production during the convalescence period, and the high cost of the treatment. The work of these authors showed that from calving until 60 days after diagnosis, dairy cows with LDA produced $557 \mathrm{~kg}$ less milk than the healthy animals, and $30 \%$ of the losses happened before the diagnosis. Besides, cows with DA were twice more susceptible to other diseases than the animals without health problems.

Estimated economic loss in a case of DA is between 250 and 450 American dollars, depending on the chosen treatment (Bartlett et al., 1995). In the United States, Geishauser et al. (2000) calculated an annual loss higher than 220 million dollars due to DA. With a more accurate diagnosis and a more effective treatment, economic losses caused by this illness, which is more frequent in intensive systems of production, can be avoided.

The aim of this work was to establish the relations between metabolic events that occur during LDA in high producing dairy cows in one of the main dairy area in Rio Grande do Sul, and to establish auxiliaries in the prognosis through the determination of hematological, biochemical and ruminal parameters which could allow an opportune intervention before and after the treatment.

\section{Materials and Methods}

In the present work, 40 Holstein cows were evaluated. Twenty of them had positive diagnosis for left displacement of abomasum (LDA), and twenty healthy cows were used as control. All of the animals belonged to seven commercial herds under intensive production system in the conditions of the Plateau Region in Rio Grande do Sul, Brazil.

The positive clinical diagnosis of DA was established by the characteristic metallic sound "ping" to the percussion with auscultation, and was confirmed in the moment of the surgery procedure. In the animals considered positive, the technique of abomasopexy by the left side was performed, according to Fubini \& Ducharme (2004). Healthy cows from the same herd that presented age, lactation numbers, and milking days similar to the animals with DA were considered as control animals. Samples of animals in the control group were collected on the same day as the ones of animals with DA, soon after surgery procedure. As a requisite, the studied DA cases have as common characteristic the average milking production above $25 \mathrm{~kg}$ per day. Samples of blood, urine, and ruminal liquid were collected in the moment of the LDA diagnosis, before surgery. In all cases, calving dates, previous milking production of the cow, body weight (measured by weight strip), body condition score (1-5 scale), number of lactations, and degree of dehydration were recorded. The basis of the feeding in the selected herds was tifton pasture (Cynodon nlemfluensis), black oat (Avena strigosa), ryegrass (Lolium multiflorum), corn silage, concentrate, and mineral supplement.

From the 40 selected animals, samples of blood were collected through coccygeal venipunction using vacutainer tubes with EDTA, and tubes without anticoagulant. The blood collections were made before surgery procedure and before any medicinal treatment, and they were kept refrigerated until arrival at the lab. EDTA tubes were used for blood counting. Total accounts of erythrocytes and leucocytes were made by the technique of microdilution and Neubauer chamber counting. Packed cell volume (PCV) was determined by microcentrifugation, and hemoglobin was measured through colorimetric technique of potassium cyanide. The differential counting of leucocytes was made from blood smears treated with Wright dye. Blood samples without anticoagulant were centrifuged (2,500 rpm for $15 \mathrm{~min}$ ), serum was withdrawn and stored at $-20^{\circ} \mathrm{C}$ for 
biochemical analyses, which were performed by spectrophotometric methods. The examined profile included albumin, total protein, cholesterol, urea, triglycerides, calcium, magnesium, aspartate aminotransferase, creatinine, beta-hydroxybutyrate, lactate and free fatty acids. Sodium and potassium values were determined by flame photometer.

Urine samples were collected through induction by perineal massage. The first jets of urine were discarded. A minimum $200 \mathrm{~mL}$ were collected in sterilized recipients. Samples were put under refrigeration and analyzed before 24 hours after collection. Urine analyses made in field were $\mathrm{pH}$ determination and presence detection of ketonic bodies through reagent strips. The complete urine analysis was performed in the lab, and included sediment and physicochemical analysis.

Samples of ruminal liquid were collected through a ruminal catheter of double duct with a vacuum bomb adapted to cattle, and a tubular open-mouth. The collects $(250 \mathrm{~mL})$ were performed at least three hours after the last ingestion of food. First obtained jets of ruminal liquid were discarded as to reduce the effect of saliva dragged by the catheter. The liquid obtained was filtered through adaptation of double gauze inside a funnel. In one part of the filtered liquid, $\mathrm{pH}$ was determined through digital potenciometer and through reagent strips for comparison. The other part of the liquid was decanted into two test tubes, previously calibrated to a volume of $10 \mathrm{~mL}$ each. Ten milliliters of filtered ruminal juice were put in one of the control tubes. The other tube contained $0.5 \mathrm{~mL}$ of a solution $0.03 \%$ methylene blue, in which $9.5 \mathrm{~mL}$ of filtered ruminal liquid were added to complete the final volume of $10 \mathrm{~mL}$. Time was measured from the moment the solution was mixed to the ruminant liquid. The recorded time corresponded to the final disappearance of the blue color, when compared to the proof tube, and it was registered as RTMB (reduction time of methylene blue) in minutes. When permission was obtained from the owner, samples of ruminal liquid were also collected by means of ruminocentesis through a $20 \mathrm{~mL}$ syringe and disposable needle.

Descriptive analyses were run and normality and homocedasticity were tested. ANOVA and linear regression were performed, using SAS 9.1 (SAS Institute, 2003) previously applying a logarithmical transformation $(\log \mathrm{x})$ when necessary, and grouping was obtained through Pearson's correlation analysis. Probability level was $\mathrm{p}<0.05$.

\section{Results and Discussion}

Brazilian scientific literature is rare about the epidemiology of left displacement of the abomasum (LDA). Silva et al. (2004) reported that digestive problems, mainly the abomasum displacement, responded for $0.65 \%$ causes of discarding of dairy cows.

In the present work, animals with LDA presented the same average days in milk, as those of the control group (Table 1). Therefore, the pairing of the samples was obtained, because the animals showed no different metabolic phases, which occur during lactation. Shaver et al. (1997) reported that from 80 to $90 \%$ LDA cases are diagnosed in the first month after calving, and Constable et al. (1992) stated that the period of greater risk of suffering LDA is the first month after calving. Some authors report that first lactation is a period with high risks of LDA developing, which can happen due to probable low level of social integration of the calf, and the nutritional adaptation (Jubb et al., 1991). Mean age of the animals with LDA was $4.63 \pm 2.33$ years old, i.e., relatively young animals, with low level of lactations $(2.95 \pm 1.9)$. They were, therefore, the most susceptible ones.

There was a difference in milk production, which was evaluated in the moment of the affection diagnosis, between the group with LDA and the control group (Table 1). Detilleux et al. (1997) reported that cows with LDA presented a reduction of $557 \mathrm{~kg}$ of milk in a lactation of 305 days, compared to control cows, and they also state that $30 \%$ of this loss occurs before the diagnosis of the disorder.

Animals with LDA presented lower weight than those of the control group, as well as smaller body condition score (Table 1). According to Van Winden et al. (2003), who evaluated animals before calving until the moment of LDA diagnosis, cows with LDA presented lower food

Table 1. Average, standard deviation, probability value (analysis of variance) of productive parameters in dairy cows with left displaced abomasum, and control group.

\begin{tabular}{lccr}
\hline Parameter & $\begin{array}{c}\text { Displacement } \\
\text { of abomasum }\end{array}$ & Control & P \\
\hline Days in milk & $33.60 \pm 46.27$ & $34.50 \pm 47.63$ & 0.952 \\
Age (years) & $4.63 \pm 2.3$ & $4.42 \pm 1.7$ & 0.756 \\
Milk production $\left(\mathrm{kg} \mathrm{day}^{-1}\right)$ & $6.72 \pm 3.85 \mathrm{a}$ & $26.86 \pm 8.36 \mathrm{~b}$ & $<0.001$ \\
Body weight $(\mathrm{kg})^{\text {BCS }^{(1)}}$ & $566.5 \pm 51.12 \mathrm{a}$ & $602.9 \pm 45.68 \mathrm{~b}$ & 0.025 \\
\hline
\end{tabular}

${ }^{(1)} \mathrm{BCS}$ : body condition score (1-5). 
consumption and suffered body weight decrease. Cameron et al. (1998) suggest that the lower consumption and little ruminant fulfilling causes the abomasum displacement to the left, even before the appearance of a clinical case.

There was no difference in the $\mathrm{pH}$ of the ruminal liquid collected through catheter between the group with LDA and the control group. Also, no difference was showed in the $\mathrm{pH}$ of ruminal liquid evaluated either by digital potenciometer or by reagent strip (Table 2). The reagent strip, then, becomes a practical indicator for field evaluation.

The collection of ruminal liquid through ruminocentesis was made in 12 animals. In those samples, there was no significant difference between LDA group and the control one for $\mathrm{pH}$ measured in digital potenciometer. Enemark et al. (2003) observed difference in the $\mathrm{pH}$ of the ruminant fluid when it was collected by catheter or by ruminocentesis. Due to contamination of the sample with animal saliva, a higher value in $\mathrm{pH}$ is expected in the material collected through catheter. Duffield et al. (2004) reported that, in average, ruminocentesis samples presented lower levels of $\mathrm{pH}$ - between 0.44 and 0.35 - compared to extraction through oral catheter. In the present work, a greater $\mathrm{pH}(\mathrm{p}<0.001)$ was obtained through catheter than the one collected by ruminocentesis. This last technique represents a more dependable sampling. In general, $\mathrm{pH}$ was within normality for animals fed with high content concentrate diets, i.e., between 6.0 and 6.6 (Campos et al., 2006).

The reduction time of methylene blue (RTMB) was significantly greater in the group with LDA, when comparing to the control group (Table 2). According to

Table 2. Average, standard deviation, probability value (analysis of variance) of ruminal profile indicators of dairy cows with left displaced abomasum, and control group.

\begin{tabular}{|c|c|c|c|}
\hline Parameter & $\begin{array}{c}\text { Displacement of } \\
\text { abomasum }\end{array}$ & $\mathrm{Co}$ & $\mathrm{P}$ \\
\hline & & 7.0 & 0.978 \\
\hline & & 7.03 & 0.810 \\
\hline & 5.90 & 6.14 & 0.382 \\
\hline & $6.05 \pm 0.42$ & $6.36 \pm 0.27$ & 0.219 \\
\hline $\mathrm{RTMB}^{(5)}$ & $4.70 \pm 1.89 \mathrm{a}$ & $1.66 \pm 1.14 b$ & $<0.001$ \\
\hline
\end{tabular}

${ }^{(1)}$ Ruminal liquid colleted through a ruminal catheter, and rumen $\mathrm{pH}$ measured with reagent strip. ${ }^{(2)}$ Ruminal liquid colleted through a ruminal catheter, and rumen $\mathrm{pH}$ measured with digital potenciometer. ${ }^{(3)}$ Ruminal liquid colleted through ruminocentesis, and rumen $\mathrm{pH}$ measured with reagent strip. ${ }^{(4)}$ Ruminal liquid colleted through ruminocentesis, and rumen $\mathrm{pH}$ measured with digital potenciometer. ${ }^{(5)} \mathrm{RTMB}$ : reduction time of methylene blue (min).
Bouda et al. (2000), the RTMB expected under normal conditions of ruminal functioning must be of three minutes at most. Therefore, in the present work, there was a loss in the ruminal microflora of the animals with LDA. This is an important point to be considered in the moment of treating the animal.

Serum lactate values were higher in animals with LDA than in control ones (Table 3). Howard et al. (1999) found that metabolic acidosis, caused by long stand volvulus in cattle, decreases tissue perfusion, secondary to dehydration, and promotes anaerobic generation of lactate.

The concentration of nonesterified fatty acids (NEFA) indicates mobility of fatty deposits, and thus, energetic deficit in ruminants (Kaneko et al., 1997). The seric levels of NEFA found in the group with LDA were higher than ones of the control group, which indicates an energetic deficit in the animals with LDA (Table 3). Van Winden \& Kuiper (2003), Van Winden et al. (2003) and LeBlanc et al. (2005) found similar values of NEFA in cows in the beginning of the lactation phase with and without LDA.

The serum values of beta-hydroxybutyrate (BHB) found were significantly different in the animals with LDA and the control group. LeBlanc et al. (2005) found higher values of BHB in animals with LDA than in the

Table 3. Average, standard deviation and probability value (analysis of variance) of hematological and biochemical profile of dairy cows with left displaced abomasum, and control group.

\begin{tabular}{|c|c|c|c|}
\hline Parameter $^{(1)}$ & $\begin{array}{l}\text { Displacement of } \\
\text { abomasum }\end{array}$ & Control & $P$ \\
\hline Sodium $\left(\mathrm{mmol} \mathrm{L}^{-1}\right)$ & $148.6 \pm 10.67$ & $148.6 \pm 7.59$ & 0.960 \\
\hline Potassium $\left(\mathrm{mmol} \mathrm{L}^{-1}\right)$ & $5.33 \pm 0.97$ & $5.80 \pm 0.99$ & 0.123 \\
\hline Magnesium $\left(\mathrm{mg} \mathrm{dL}^{-1}\right)$ & $3.15 \pm 1.49$ & $3.02 \pm 0.53$ & 0.949 \\
\hline Calcium $\left(\mathrm{mg} \mathrm{dL}^{-1}\right)$ & $11.86 \pm 3.9$ & $11.35 \pm 1.76$ & 0.560 \\
\hline Creatinine $\left(\mathrm{mg} \mathrm{dL}^{-1}\right)$ & $1.455 \pm 0.31$ & $1.441 \pm 0.18$ & 0.468 \\
\hline Lactate $\left(\mathrm{mg} \mathrm{dL}^{-1}\right)$ & $32.29 \pm 2.99 \mathrm{a}$ & $24.43 \pm 2.41 \mathrm{~b}$ & 0.047 \\
\hline Total Protein $\left(\mathrm{g} \mathrm{L}^{-1}\right)$ & $80.03 \pm 12.65 a$ & $87.64 \pm 7.71 \mathrm{~b}$ & 0.033 \\
\hline Urea $\left(\mathrm{mg} \mathrm{dL}^{-1}\right)$ & $43.58 \pm 18.21 \mathrm{a}$ & $35.39 \pm 11.21 b$ & 0.048 \\
\hline Albumin $\left(\mathrm{g} \mathrm{L}^{-1}\right)$ & $33.24 \pm 6.72 \mathrm{a}$ & $39.06 \pm 6.78 b$ & 0.012 \\
\hline $\operatorname{AST}\left(\mathrm{U} \mathrm{L}^{-1}\right)$ & $141.8 \pm 42.60 \mathrm{a}$ & $93.37 \pm 16.0 \mathrm{~b}$ & 0.000 \\
\hline Cholesterol $\left(\mathrm{mg} \mathrm{dL}^{-1}\right)$ & $81.32 \pm 39.26 \mathrm{a}$ & $140 \pm 61.21 \mathrm{~b}$ & 0.001 \\
\hline $\mathrm{BHB}\left(\mathrm{mmol} \mathrm{L}^{-1}\right)$ & $1.14 \pm 1.098 \mathrm{a}$ & $0.699 \pm 0.283 b$ & 0.001 \\
\hline $\operatorname{NEFA}\left(\mathrm{mmol} \mathrm{L}^{-1}\right)$ & $1.26 \pm 0.26$ & $0.57 \pm 0.10$ & $<0.01$ \\
\hline Hematocrite (\%) & $32.21 \pm 3.52 \mathrm{a}$ & $28.63 \pm 3.59 b$ & 0.004 \\
\hline Hemoglobin $\left(\mathrm{g} \mathrm{dL}^{-1}\right)$ & $10.34 \pm 1.11 \mathrm{a}$ & $9.36 \pm 1.06 \mathrm{~b}$ & 0.019 \\
\hline $\mathrm{pH}$ urine & $7.38 \pm 1.28 \mathrm{a}$ & $8.33 \pm 0.38 b$ & 0.005 \\
\hline
\end{tabular}

${ }^{(1)}$ Different letters in the same line have significant difference. (2)AST: aspartate aminotransferase; BHB: beta-hydroxybutyrate; NEFA: nonesterified fatty acids. 
control group. In these authors' work, the average days of lactation were $3.9 \pm 1.9$ days, thus constituting animals in the beginning of lactation, which suggests that the response to the energetic balance in peripartum is one of the important factors in LDA pathogeny. It can be suggested that LDA diagnosis, in the production system, is late (33.60 \pm 46.27 days). So, increased values of BHB are associated to a greater LDA risk. The present data confirm the findings of Van Winden et al. (2003), in which animals with LDA had higher levels of BHB.

Serum total protein values were lower in the group with LDA (Table 3), which can be explained by the alimentary privation of the affected animals. This result suggests that animals with LDA suffer a period of food restriction that harms the protein metabolism. Van Winden et al. (2003) found lower levels of dry mater consumption in animals with LDA (-9.5 kg per day).

Values of serum albumin were lower in cows with LDA than in control ones (Table 3). This is due to the alimentary privation period caused by the affection (Kaneko et al., 1997). In LDA, the pyloro and the duodenum, as well as the omento, are displaced to the left (Van Winden et al., 2002). There can exist, therefore, bad absorption, which would result in low levels of albumin found in the current work. This anatomical change may also have contributed for the lower cholesterol levels, found in animals with LDA compared with control ones. One of the main reasons is the abnormality in blood irrigation of the pancreatic parenchyma, caused by the anatomic change of the omento and the duodenum due to LDA (Kalaitzakis et al., 2006).

The serum urea levels were higher in animals with LDA than in animals from the control group. These values suggest an endogenous protein degradation, due to alimentary restriction and to the energy deficiency (Kaneko et al., 1997).

Van Winden et al. (2003) found increased values of the enzyme aspartate aminotransferase (AST) in cows, before revealing LDA signals. This enzyme is an indicator of hepatic or muscular injury. A long feed deprivation of animals with LDA, as well as the sudden increase of energy need soon after calving, mainly in high production dairy cattle, can induce to hepatic lipidosis. It is suggested, in the present work, that animals with LDA presented hepatic lipidosis due to increased values of AST, NEFA, BHB, and diminished values of albumin and cholesterol (Table 3). Also, the increase in blood levels of this enzyme can be result in protein mobilization of the muscles to gluconeogenesis from amino acids (Herdt, 2000).

Other studied metabolites were found inside reference values, and showed no statistical difference. Van Winden \& Kuiper (2003) found inferior values of calcium, in the second week of lactation of animals with LDA, when compared to the control group. In the current work, difference for this metabolite was not found.

The $\mathrm{pH}$ of urine was lower in animals with LDA, which can be caused by higher lactacidemy in the affected cows (Table 3). Also, sodium retention and hydrogen excretion by urine, due to dehydration, may have contributed to that effect (Guard et al., 1993).

Animals with LDA showed increased values for PCV and hemoglobin than the ones in the control group. These values indicate a slight degree of dehydration in animals with LDA. The accumulation of liquid inside the abomasum also contributed to water deficiency in animals with LDA (Kaneko et al., 1997).

The metabolites that presented meaningful difference in the general model were used in the regression model. Values found for the models are in Table 4. The AST models did not seem to be the most exact indicators, as they can be altered in any kind of hepatic lesion or muscular effort (Kaneko et al., 1997). The best contributors to LDA diagnosis were milk production and $\mathrm{RTMB}$, with $\mathrm{R}=0.99$. In the second step of the analysis, these elements were withdrawn, and new parameters were included in the matrix, where body condition score, cholesterol and albumin were the most meaningful ones.

Table 4. Selected parameters in regression model as auxiliaries in the diagnosis of the left displaced abomasum (LDA).

\begin{tabular}{clcc}
\hline Model & Selected parameter ${ }^{(1)}$ & Equation & $\mathrm{R}$ \\
\hline 1 & RTMB & $\mathrm{Y}=2.0105-0.166 \mathrm{RTMB}$ & 0.834 \\
2 & RTMB, hematocrite & $\mathrm{Y}=3.713-0.163 \mathrm{RTMB}-0.055$ hematocrite & 0.916 \\
3 & RTMB, hematocrite, urea & $\mathrm{Y}=3.879-0.157 \mathrm{RTMB}-0.5$ hematocrite -0.008 urea & 0.960 \\
4 & RTMB, hematocrite, urea, BCS & $\mathrm{Y}=2.913-0.121 \mathrm{RTMB}-0.44$ hematocrite -0.007 urea $+0.221 \mathrm{BCS}$ & 0.983 \\
5 & RTMB, hematocrite, urea, BCS, BHB & $\mathrm{Y}=2.931-0.158 \mathrm{RTMB}-0.43$ hematocrite -0.008 urea $+0.198 \mathrm{BCS}+0.141 \mathrm{BHB}$ & 0.991 \\
\hline
\end{tabular}

${ }^{(1)}$ RTMB: reduction time of methylene blue; BHB: beta-hydroxybutyrate; BCS: body condition score. 
Afterwards, the five preceding parameters were withdrawn, and the meaningful ones were BHB and urea.

\section{Conclusions}

1. Milk production, body weight and body condition score decrease in animals with left displacement of the abomasum (LDA).

2. The $\mathrm{pH}$ indicative reagent strip is a good tool to determine the rumen $\mathrm{pH}$ in the field.

3. Serum values of lactate, beta-hydroxybutyrate, nonesterifield fatty acids, urea and aspartate aminotransferase increase in animals with LDA, while total protein, albumin and cholesterol decrease; these metabolites constitute indicators for the prognosis and treatment of this disorder.

4. Among the used parameters, reduction time of methylene blue, milk production, urea, body condition score, cholesterol, albumin and beta-hydroxybutyrate are the most efficient in the characterization of the LDA.

\section{Acknowledgements}

To producers of dairy cattle who cooperated with this work; to Conselho Nacional de Desenvolvimento Científico e Tecnológico, for scholarship.

\section{References}

BARTLETT, P.C.; KOPCHA, M.; COE, P.H.; AMES, N.K.; RUEGG, P.L.; ERSKINE, R.J. Economic comparison of pyloroomentopexy vs. roll-and-toggle procedure for the treatment of left displacement of the abomasums in dairy cattle. Journal of the American Veterinary Medical Association, v.206, 11561162,1995

BOUDA, J.; QUIROZ-ROCHA, G.F.; GONZÁLEZ, F.H.D. Importância da coleta e análise de líquido ruminal e urina. In: GONZÁLEZ, F.H.D.; BORGES, J.B.; CECIM, M. (Ed.). Uso de provas de campo e laboratório em doenças metabólicas e ruminais em bovinos. Porto Alegre: UFRGS, 2000. p.13-16.

CAMERON, R.E.B.; DYK, P.B.; HERDT, T.H.; KANEENE, J.B.; MILLER, R.; BUCHOLTZ, H.F.; LIESMAN, J.S.; VANDEHAAR, M.J.; EMERY, R.S. Dry cow diet, management, and energy balance as risk factors for displaced abomasum in high producing dairy herds. Journal of Dairy Science, v.81, p.132-139, 1998.

CAMPOS, R.; GONZÁLEZ, F.; COLDEBELLA, A.; CARDOSO, F. Indicadores do ambiente ruminal e suas relações com a composição do leite e células somáticas em diferentes períodos da primeira fase da lactação em vacas de alta produção. Ciência Rural, v.36, p.525530, 2006

CONSTABLE, P.D.; MILLER, G.Y.; HOFFSIS, G.F.; HULL, B.L.; RINGS, D.M. Risk factors for abomasal volvulus and left abomasal displacement in cattle. American Journal of Veterinary Research, v.53, p.1184-1192, 1992.

COPPOCK, C.E.; NOLLER, C.H.; WOLFE, S.A.; CALLAHAN, C.J.; BAKER, J.S. Effect of forage-concentrate ratio in complete feeds fed ad libitum on feed intake prepartum and the occurrence of abomasal displacement in dairy cows. Journal of Dairy Science, v.55, p.783-789, 1972.

DETILLEUX, J.C.; GROHN, Y.T.; EICKER, S.W.; QUAAS, R.L. Effects of left displaced abomasum on test day milk of Holstein cows. Journal of Dairy Science, v.80, p.121-126, 1997.

DUFFIELD, T.; PLAIZIER, J.C.; FAIRFIELD, A.; BAGG, R.; VESSIE, G.; DICK, P.; WILSON, J.; ARAMINI, J.; MCBRIDE, B. Comparison of techniques for measurement of rumen $\mathrm{pH}$ in lactating dairy cows. Journal of Dairy Science, v.87, p.59-66, 2004.

ENEMARK, J.M.D.; PETERS, G.; JØRGENSEN, R.J. Continuous monitoring of rumen $\mathrm{pH}$ - a case study with cattle. Journal of Veterinary Medicine, Series A, v.50, p.62-66, 2003.

FUBINI, S.L.; DUCHARME, N.G. Farm animal surgery. St. Louis: W.B. Saunders, 2004. 607p.

GEISHAUSER, T.; LESLIE, K.; DUFFIELD, T. Metabolic aspects in the etiology of displaced abomasum. Veterinary Clinics of North America: Food Animal Practice, v.16, p.255-265, 2000.

GEISHAUSER, T.; LESLIE, K.E.; DUFFIELD, T.; EDGE, V. An evaluation of milk ketone tests for the prediction of left displaced abomasum in dairy cows. Journal of Dairy Science, v.80, p.31883192, 1997a.

GEISHAUSER, T.; SHOUKRI, M.; KELTON, D.; LESLIE, K. Analysis of survivorship after displaced abomasum is diagnosed in dairy cows. Journal of Dairy Science, v.81, p.2346-2353, 1998.

GUARD, C. Disorders of the organ systems: diseases of the alimentary system. In: SMITH, B.P. Tratado de medicina interna de grandes animais. São Paulo: Manole, 1993. p.792-795.

HERDT, T.H. Variability characteristics and test selection in herd level nutritional and metabolic profile testing. Veterinary Clinics of North America: Food Animal Practice, v.16, p.387-403, 2000.

HOWARD, J.L.; SMITH, R.A. Current veterinary therapy - food animal practice 4. $4^{\text {th }}$ ed. St. Louis: W.B. Saunders, 1999. 766p.

JUBB, T.F.; MALMO, J.; DAVIS, G.M.; VAWSER, A.S. Left-side displacement of the abomasum in dairy cows at pasture. Australian Veterinary Journal, v.68, p.140-142, 1991.

KALAITZAKIS, E.; ROUBIES, N.; PANOUSIS, N.; POURLIOTIS, K.; KALDRYMIDOU, E.; KARATZIAS, H. Evaluation of ornithine carbamoyl transferase and other serum and liver-derived analytes in diagnosis of fatty liver and postsurgical outcome of left-displaced abomasum in dairy cows. Journal of the American Veterinary Medical Association, v.229, p.1463-1471, 2006.

KANEKO, J.J.; HARVEY, J.W.; BRUSS, M.L. Clinical biochemistry of domestic animals. $5^{\text {th }}$ ed. San Diego: Academic Press, 1997. 932p.

LEBLANC, S.J.; LESLIE, K.E.; DUFFIELD, T.F. Metabolic predictors of displaced abomasum in dairy cattle. Journal of Dairy Science, v.88, p.159-170, 2005. 
RADOSTITS, O.M.; GAY, C.C.; BLOOD, D.C.; HINCHCLIFF, K.W. Veterinary medicine. $9^{\text {th }}$ ed. St. Louis: W.B. Saunders, 2000. $1877 \mathrm{p}$.

SARASHINA, T.; ICHIJO, S.; TAKAHASHI, J.; OSAME, S. Origin of abomasum gas in the cows with displaced abomasum. Japanese Journal of Veterinary Science, v.52, p.371-378, 1991.

SAS INSTITUTE. SAS/STAT software: changes and enhancements through release 9.1. Cary: SAS Institute, 2003. 5136p.

SHAVER, R.D. Nutritional risk factors in the etiology of left displaced abomasum in dairy cows: a review. Journal of Dairy Science, v.80, p.2449-2453, 1997.

SILVA, L.A.F.; SILVA, E.B.; SILVA, L.M.; TRINDADE, B.R.; SILVA, O.C.; ROMANI, A.F.; FIORAVANTI, M.C.S.; SOUSA, J.N.; FRANCO, L.G.; GARCIA, A.M. Causas de descarte de fêmeas bovinas leiteiras adultas. Revista Brasileira de Saúde e Produção Animal, v.5, p.9-17, 2004.

TRENT, A.M. Surgery of the bovine abomasum. Veterinary Clinics of North America: Food Animal Practice, v.6, p.399-448, 1990.

VAN WINDEN, S.C.L.; BRATTINGA, C.R.; MÜLLER, K.E.; NOORDHUIZEN, J.P.T.M. Position of the abomasum in dairy cows during the first six weeks after calving. The Veterinary Record, v.151, p.446-449, 2002.

VAN WINDEN, S.L.C.; JORRITSMA, R.; MÜLLER, K.E.; NOORDHUIZEN, J.P.T.M. Feed intake, milk yield, and metabolic parameters prior to left displaced abomasum in dairy cows. Journal of Dairy Science, v.86, p.1465-1471, 2003.

VAN WINDEN, S.C.L.; KUIPER, R. Left displacement of the abomasum in dairy cattle: recent developments in epidemiological and etiological aspects. Veterinary Research, v.34, p.47-56, 2003.

Received on Setember 10, 2007 and accepted on December 10, 2007 